\title{
MEASUREMENTS OF SMALL ALPINE GLACIERS: EXAMPLES FROM SLOVENIA AND AUSTRIA
}

MERJENJE MALIH ALPSKIH LEDENIKOV: PRIMERI IZ SLOVENIJE IN AVSTRIJE

\section{Mihaela Triglav Čekada, Matija Zorn, Viktor Kaufmann, Gerhard Karl Lieb}

UDC: $528.4+528.7(234.2)(497.4)(436)$

\begin{abstract}
In the last century and a half, average summer temperatures have slowly been rising worldwide. The most observable consequence of this is the change in glacier sizes. For monitoring glacier area and volume, various measuring techniques exist-from measurements with a measuring tape and geodetic measurements to remote sensing and photogrammetry. A comparison of different measuring techniques on two Slovenian glaciers (the Triglav and Skuta glaciers) and two Austrian glaciers (the Gössnitzkees and Hornkees glaciers) is made. A long-term glacial retreat trend is presented for the Gössnitzkees, Hornkees, and Triglav glaciers because these glaciers can be monitored throughout the entire twentieth century by means of archival data. Despite their different sizes, the annual trend of glacial retreat was approximately the same in the period between 1929 and 2006.
\end{abstract}

\section{KEY WORDS}

small alpine glaciers, geodetic measurements, photogrammetric measurements, Austria, Slovenia

\section{Klasifikacija prispevka po COBISS-u: 1.02 IZVLEČEK}

$V$ zadnjem stoletju in pol se globalne povprečne letne temperature stalno dvigajo. Ena od vidnih posledic tega je spreminjanje velikosti ledenikov. Za spremljanje površinskih in prostorninskih sprememb ledenikov obstajajo številne metode, od meritev z merskim trakom, klasičnih geodetskih izmer do daljinskega zaznavanja in fotogrametrije. Uporaba nekaterih je predstavljena na dveh slovenskih (Triglavski ledenik, Ledenik pod Skuto) in dveh avstrijskih ledenikih (Gössnitzkees in Hornkees). Predstavljen je tudi dolgoročen trend zmanjševanja ledenikov Gössnitzkees, Hornkees in Triglavskega ledenika, ki ga na podlagi različnih arhivskih podatkov lahko spremljamo že od začetka 20. stoletja. Čeprav so obravnavani ledeniki različno veliki, izkazujejo primerljiv letni trend zmanjševanja v obdobju med letoma 1929 in 2006.

\section{KLJUČNE BESEDE}

mali alpski ledeniki, geodetska izmera, fotogrametrična izmera, Avstrija, Slovenija

\section{INTRODUCTION}

Alpine glaciers are an important part of hydrological and geomorphological natural heritage, and they also represent a source of drinking water and are important tourist destinations (Zäng1 and Hamberger, 2004). They can be used to monitor short-term climate changes in the Alps, and the study of their accumulation forms also reveals information about older environmental changes (Kuhn, 1979; Haeberli et al., 2007).

Measuring glaciers usually involves measuring the retreat of the glacial terminus, the reduction in 
the glacier's area or volume, or the speed of its movement. In the Alps, where glaciers are found in high-elevation areas, fieldwork is more difficult and so the first measurements were primarily made by hand, using a tape measure and compass. As early as 1878 regular measurements with a tape measure were made to measure the retreat of the terminus of the Pasterze Glacier (Pasterze am Großglockner) in Austria, the longest glacier ${ }^{1}$ in the Eastern Alps (Kienast and Kaufman, 2004; Lieb, 2004). Regular measurements of small Slovenian glaciers (the Triglav and Skuta glaciers) started being made with a tape measure in 1946 (Natek and Perko, 1999; Gabrovec, 2002, 2008).

Soon the glaciers started being measured using standard geodetic means. For example, in 1928 the standard tachymetric geodetic method was used to measure five profiles of the Pasterze Glacier. Reference points were set up on the northeastern part of the glacier, and at the opposite end of the glacier the endpoint of the profile was marked with paint on the rock. Large stones to aid measurement were placed between the reference point and the endpoint. Most of the stones were able to be used in the following years for new measurements. Each profile was measured using its own local coordinate system and so these data were not directly applicable for studying the glacier's reduction in volume. The data were not converted into a common coordinate system until 1996, when the first measures of the reference points and endpoints of the profiles were carried out using a global navigation satellite system (GNSS measurement) (Kienast and Kaufman, 2004).

In the last few decades, alpine glaciers have mostly been measured using various remote sensing methods: from terrestrial (obligue) and aerial photogrammetry to processing satellite images and using terrestrial and aerial laser scanning data (Kienast and Kaufman, 2004; Avian and Bauer, 2006; Bolch and Kamp, 2006; Haeberli et al., 2007; Kaufmann and Ladstädter, 2008a; Kaufmann and Ladstädter, 2008b; Hagg et al., 2008; Knoll and Kerschner, 2009; Abermann et al., 2009). Thus, for example, the retreat of the Pasterze Glacier from 1984 to 1990 has already been determined with the aid of Landsat satellite images (Bayr et al., 1994).

Among the approximately 900 Austrian glaciers, we decided to compare the two Slovenian glaciers to two of them that, like the Slovenian glaciers, have been subject to multiple decades of continuous standard geodetic and photogrammetric measurements and have already been monitored for a number of years by the coauthors of this paper. Emphasis is placed on presenting the methods for measuring the glaciers, and there is also a brief presentation of local trends in the retreat of small glaciers in the southeastern Alps.

\section{SLOVENIAN GLACIERS}

Slovenia has two small glaciers: the Triglav Glacier (Figures 1, 3, 4, 5, 6) and the Skuta Glacier (Figures 2, 7, 8). In comparison to larger alpine glaciers, both glaciers are located at relatively low elevations. The Triglav Glacier is located at an elevation between 2,400 to 2,500 m, and the Skuta Glacier between 2,020 and 2,120 m. The Skuta Glacier is an example of a cirque glacier

${ }^{\prime}$ In 1850 Pasterze was $11.4 \mathrm{~km}$ long, whereas in 2002 it was $8.4 \mathrm{~km}$ long and in the same time span its area had decreased from 2,650 ha to 1,850 ha (Avian and Bauer, 2006). 
in a distinctly shady area all year round that conserves it. Most of the glacier's surface is covered with debris. In contrast, the Triglav Glacier is in a sunny position. The size of the glacier at its last maximum extent during the Little Ice Age around 1850 can be judged from the remnants of moraines (Šifrer, 1963; Pavšek, 2007).

Today among the glacial features which can be found on the two glaciers is just glacial ice; the other glacial features created by the movement of ice can no longer be seen on them. During the interwar period, for example, the Triglav Glacier was still crisscrossed by many deep transverse glacial crevasses testifying to the movement of ice (Figure 1). In the first years of systematic measurement (measurements began in 1946) until around 1955 small crevasses running parallel with the glacier's movement could still be seen in the Triglav Glacier. The greatest crevasse depth was $8.6 \mathrm{~m}$ in 1950 and did not reach to the bottom of the glacier. Meze (1955) described these as very meager cracks, but from today's perspective their depth is considerable. Individual shallow longitudinal crevasses in the central part of the glacier were still observed in 1973, especially where it later proved that the glacier was the thinnest and ice had moved across a large bulge in the rock.

In the summers from 1954 to 1962 the Triglav Glacier also fed small glacial lakes. In 1954 most of the lakes were several meters wide and long (4 to $10 \mathrm{~m}$ ) with a depth of up to $90 \mathrm{~cm}$. The largest among them measured approximately $100 \mathrm{~m}^{2}$ (Meze, 1955).

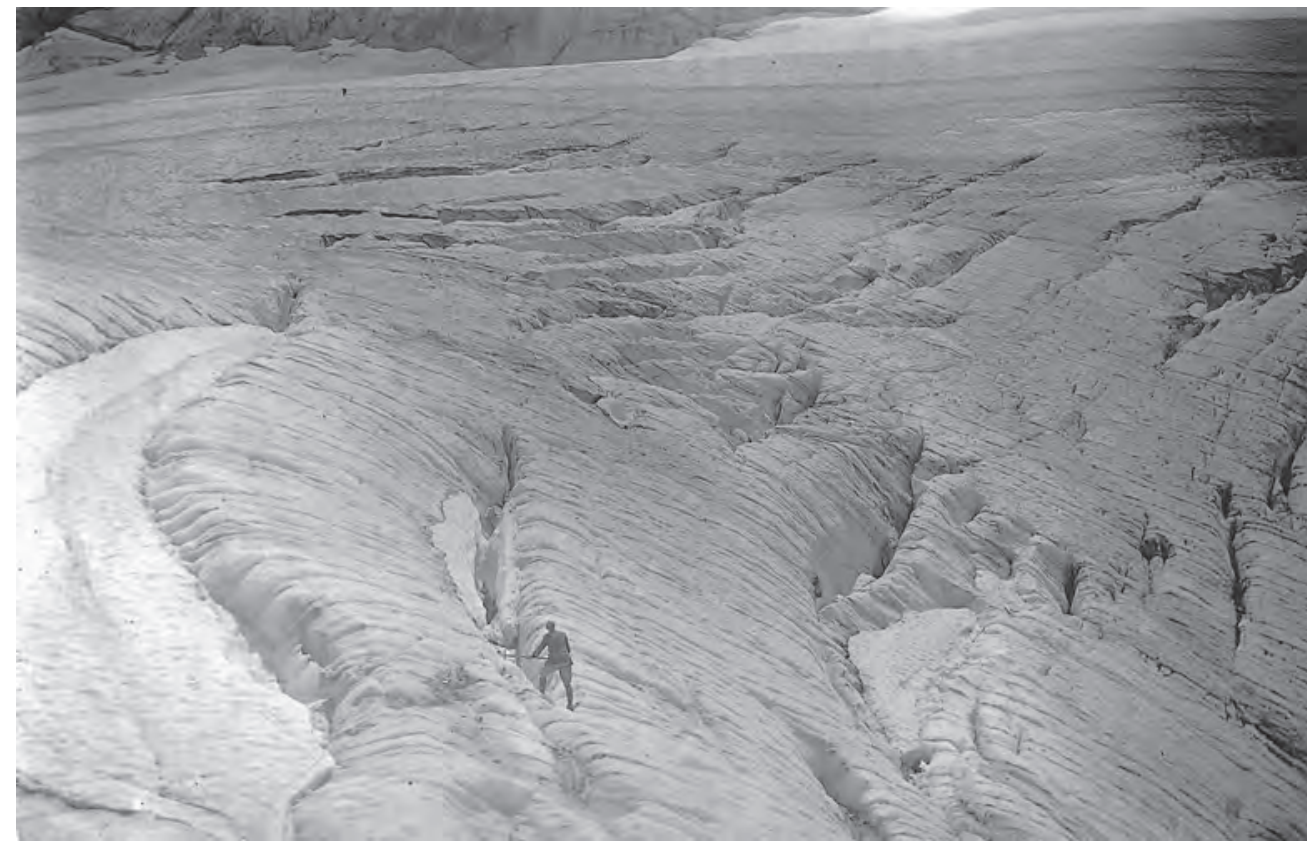

Figure 1: Transverse crevasses on the Triglav Glacier in 1924 (Kunaver, 1949) (photo: Josip Kunaver).

The Skuta Glacier also had crevasses. They were first mentioned in a report on a mountain accident in 1913 (Figure 2); they were between 10 and $15 \mathrm{~m}$ deep. On the upper, steepest part of the Skuta Glacier some transverse crevasses were still observed in 1973. According to 


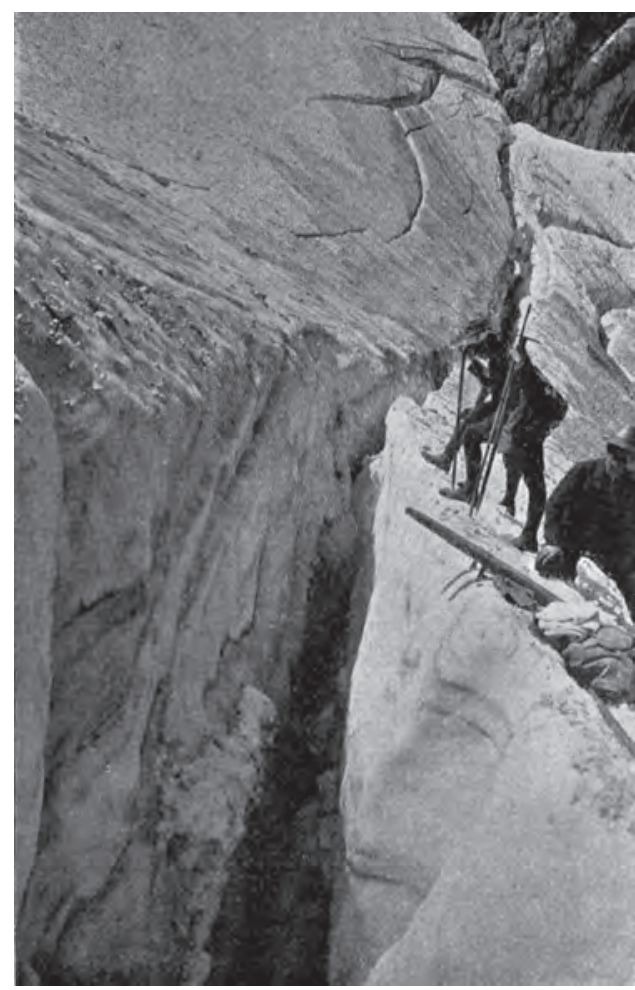

Figure 2: Transverse crevasse on the Skuta Glacier in 1913 (Kunaver, 1913) (photo: Josip Kunaver).

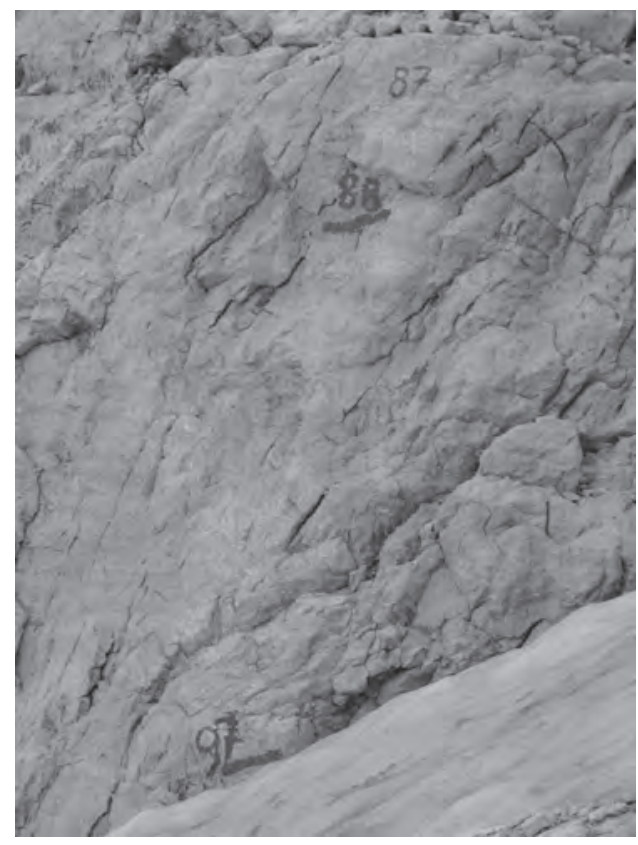

Figure 3: Ground markings (years) to help measure the vertical retreat of the Triglav Glacier with a tape measure (photo: Matija Zorn).

measurements in 1961, the largest transverse crevasse was about $60 \mathrm{~m}$ long and had a maximum depth of $7 \mathrm{~m}$; in 1966 the same crevasse was only $28 \mathrm{~m}$ long and $5 \mathrm{~m}$ deep (Meze, 1955; Sifrer and Košir, 1976).

\subsection{Measurement of the Triglav Glacier}

Regular annual measurements of the Triglav Glacier started in 1946. They are carried out by the Anton Melik Geographical Institute of Scientific Research Centre of the Slovenian Academy of Sciences and Arts (Table 1). Initially annual measurements were taken manually at the end of the melting period using a tape measure, rope, and compass. They measured the retreat of the glacier or snow from the lines and points marked on the rock around the glacier. Initially they measured the vertical retreat of the glacier from these marks, thus determining the thinning of the glacier. When the glacier started thinning more rapidly and the lower part started to collapse, they also drew lines on the rocks around the glacier showing how far the glacier had reached in a particular year (Meze, 1955; Šifrer, 1963). Many of the marks are still visible (Figure 3).

During the first years, researchers also tried to measure the movement of the glacier, but without success. In 1948 they placed two stones on the glacier whose positions were measured with a tape measure from fixed points around the glacier. The following year they found the stones again, but in dubious positions. They tried again in 1951, using four iron rods driven into the ice 
instead of stones. A month later they found only one of the iron rods in the snow. They added three more rods, but the next year they found none of them (Meze, 1955).

The first geodetic measurement using a theodolite was made in 1952, and the next one was not until 1995. In 1999 regular geodetic tachymetric measurements of the glacier and the control points around the glacier began for the needs of photogrammetric measurement of the glacier every two years (carried out by associates of the Geodetic Institute of Slovenia). In 2001 and 2005 to the tachymetric measurements the GNSS measurements were added. In 1999, 2001, and 2003 manual aerial photography of a small portion of the glacier from a helicopter and terrestrial photogrammetry using a Rolleiflex 6006 metric camera were carried out. In 2005 standard aerial photogrammetry of the broader area around the glacier was also carried out using a large-format Leica RC 30 photogrammetric camera. After 2007, tachymetric measurement with supplementary terrestrial photogrammetry using a Rolleiflex 6006 camera was carried out every year on the glacier. The results of the geodetic and photogrammetric measurements are presented at a scale of 1:1,000 (Triglav Čekada and Gabrovec, 2008; Triglav Čekada, 2012).

In 1976 the glacier started being photographed regularly (approximately once a month) with a panoramic non-metric Horizont camera (Triglav et al., 2000) from two fixed reference points in the vicinity of the Triglav Mountain Hut on Kredarica (Triglavski dom na Kredarici). The reference points were stabilized with iron rods, the ends of which have a flat camera holder. The camera was calibrated in a test field at the Vienna University of Technology in 1999. The calibration data are necessary for resampling photos in the central projection. The selection of resampled photos showing the glacier at the end of the melting period was processed with the help of an interactive method of orientation of detailed digital terrain model on an individual photo. The digital terrain model used, with a $2 \mathrm{~m} \times 2 \mathrm{~m}$ grid cell size, was created with the help of photogrammetric acquisition based on special aerophotogrammetric imaging of the glacier in 2005. The results of the acquisition were three-dimensional edges of the glacier, which are used for calculating the glacier's area and volume (Triglav Čekada et al., 2011; Triglav Čekada and Gabrovec, 2012).

Glacier data are also obtained from stereo pairs from the Cyclic Aerial Survey of Slovenia (CAS) produced using a large-format metric aerial aerophotogrammetric imaging; photography has been carried out by the Surveying and Mapping Authority of the Republic of Slovenia since the 1970s. The usual scale of the photography is $1: 17,500$. Because the glacier is not always photographed at the end of the melting period, the photos are only partially useful for studying the glacier (e.g., only the stereo pairs for 1975, 1992, 1994, and 1998). The extent and area of the glacier were photogrammetrically acquired only using stereo pairs for 1975 and 1992. Both stereo pairs were absolutely oriented in the national coordinate system using a Gauss-Krüger projection based on control points measured from the CAS 2003 stereo pair. In the 1975 stereo pair the glacier is heavily shaded by Triglav, what hinders the stereo acquisition greatly (Triglav and Gabrovec, 2008).

The contour lines of the glacier were vectorized from the 1:25,000 national topographic map of 1937. The thickness of the glacier was measured in 1999 and 2000 using ground-penetrating radar 
measurements. The greatest thickness of the glacier was $9.5 \mathrm{~m}$ in its central part, and the thickness did not exceed $3 \mathrm{~m}$ on the sides. Based on these measurements, the volume of the glacier was estimated at around $35,000 \mathrm{~m}^{3}$ (Verbič and Gabrovec, 2002).

Many archival non-metric photos made with various cameras from various reference camera stations and at various times of year are still awaiting processing. Regular photographing of the glacier from nearly fixed camera stations was already anticipated by Meze (1955) because in 1954 he marked two places near the glacier from which the glacier terminus could be photographed every year. Šifrer (1963) also reports on several fixed camera stations for photography ${ }^{2}$, of which one-Mount Begunjski vrh-is still being used every year for standard photography of the Triglav Glacier using various cameras (Figure 4).

One of the first photos of the Triglav Glacier, which is also still waiting to be processed, is the photo of the Dežman Mountain Hut (Deschmann-Haus) taken between 1887 and 1889 (Figure 5). Today the Valentin Stanič Mountain Hut (Dom Valentina Staniča) stands at this site (2,332 m).

The retreat of the Triglav Glacier between 1952 and 2006 is shown in Figure 6.
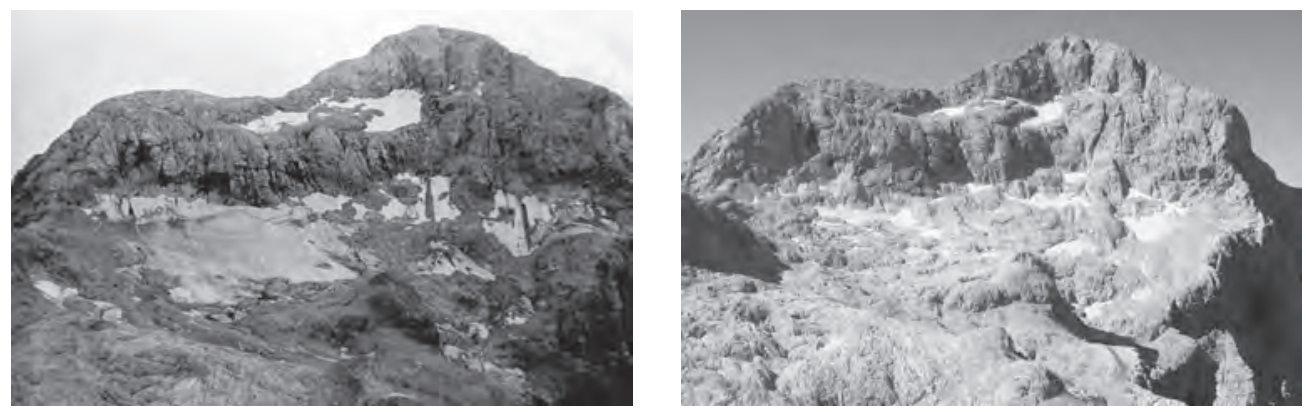

Figure 4: The Triglav Glacier seen from Mount Begunjski vrh. Left: 1986 (photo: Dušan Košir); right: 2006 (photo: Miha Pavšek).
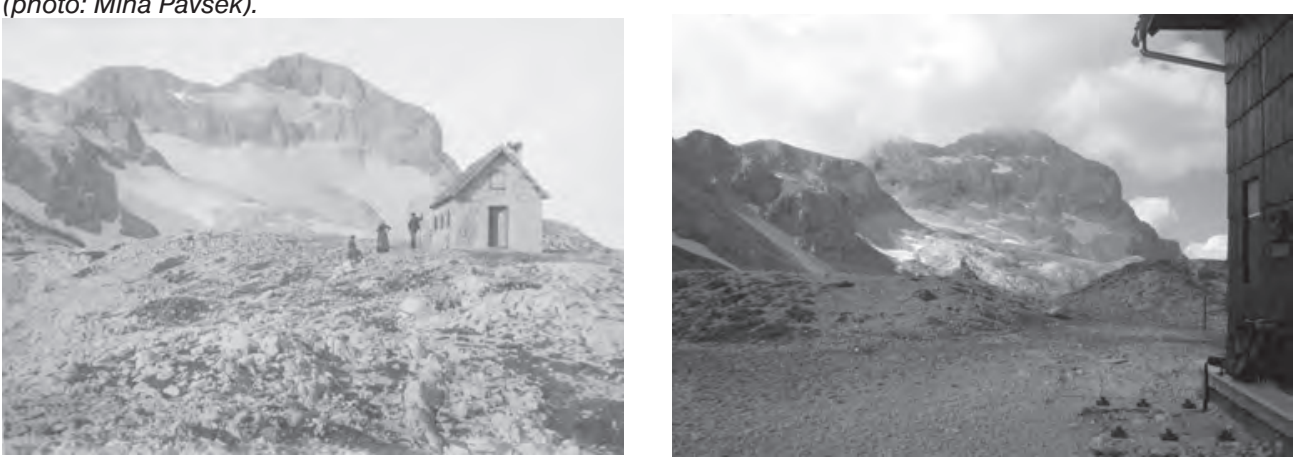

Figure 5: Left: the Dežman Mountain Hut (Deschmann-Haus) with the Triglav Glacier in the background, photographed in 1887-1889 (photo: Benedikt Lergetporer). Right: the Valentin Stanič Mountain Hut (Dom Valentina Staniča) with the Triglav Glacier in the background in 2009 (photo: Primož Gašperič).

${ }^{2}$ Anticipated points for regular photography: a point near the cumulative precipitation gauge at the east end of the glacier, Mount Glava $(2,426$ $m$ ), the wall below the Triglav Mountain Hut on Kredarica $(2,516 \mathrm{~m})$, a point on the route from Kredarica to the peak of Triglav approximately at the point where the route starts rising steeply. The last two camera stations were later selected for placement of iron rods that still serve as fixed camera stations for the Horizont camera. 


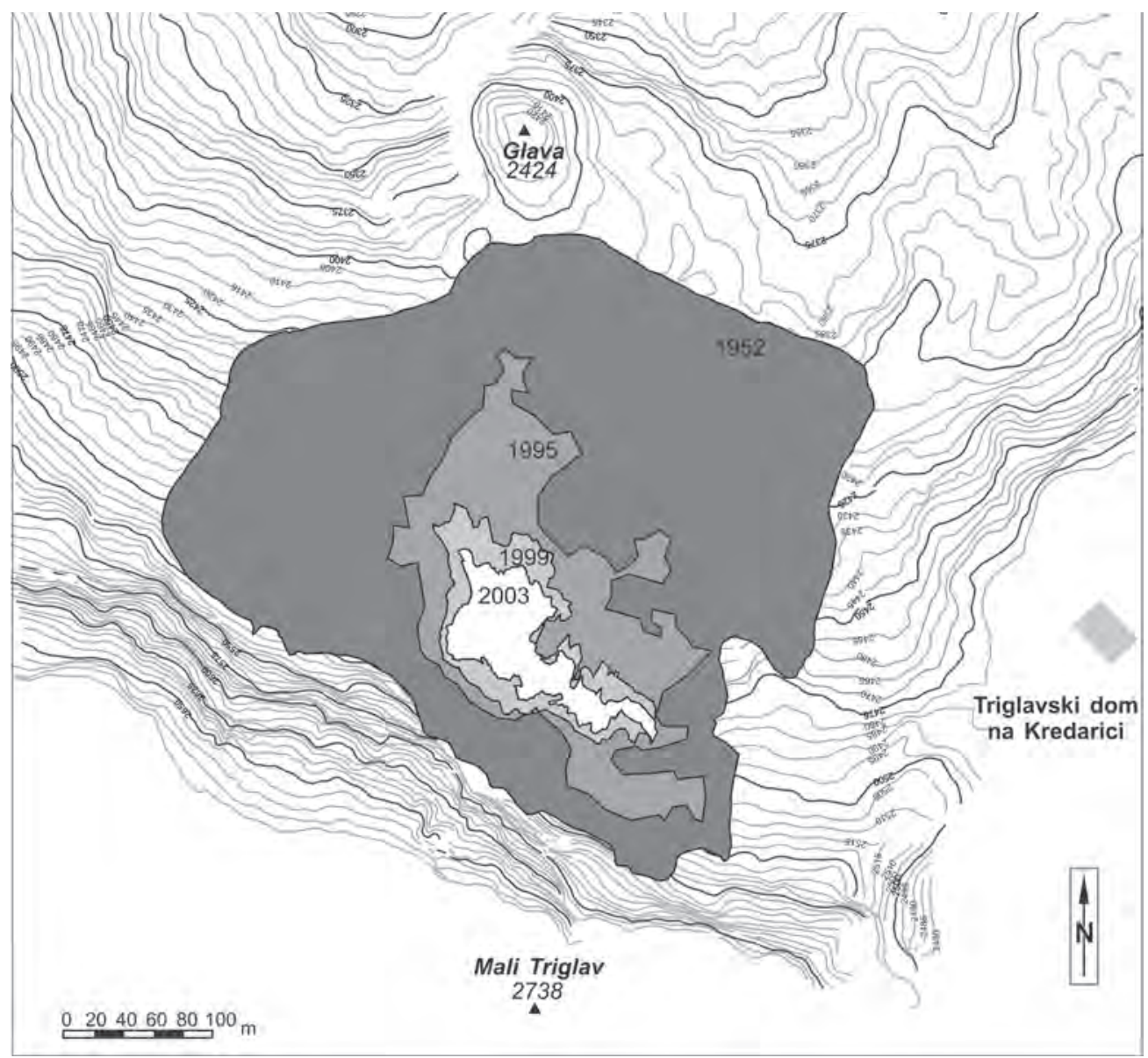

Figure 6: Reduction in area of the Triglav Glacier between 1952 and 2003 (Table 1).

\subsection{Measurement of the Skuta Glacier}

Measurements of the Skuta Glacier also began in 1946. The same methods were used with marking measuring points and using a tape measure and compass. The measuring points marked the height that the glacier reached in a particular year. Researchers measured how much the glacier had retreated vertically from the measuring points. In the first years of measurements the glacier primarily grew thinner and did not decrease in area so much. Thus they often measured the glacier's annual reduction in height by a few meters, and in recent decades by 1 to $1.5 \mathrm{~m}$ per year (Meze, 1955; Šifrer and Košir, 1976; Pavšek, 2007).

Attempts were also made in 1946, 1948, 1949, and 1951 to measure movement of the Skuta Glacier with the help of $2 \mathrm{~m}$ iron rods that were driven into the ice each year. Out of all the attempts, in 1953 they succeeded in finding only one iron rod on the glacier's surface, from which it could only be concluded that the $1.7 \mathrm{~m}$ of snow that the iron rod had originally been driven into had melted in the meantime. Because the measurements with the tape measure or 
estimates of where the iron rod had first been driven into the snow were too imprecise, it was impossible to determine the movement of the glacier (Meze, 1955).

In 1997 the Skuta Glacier was geodetically measured for the first time using the tachymetric method. The next geodetic measurements were made in 2003. Since 2007, the glacier has been geodetically measured every year. The geodetic measurements are carried out by the Karst Research Institute of Scientific Research Centre of the Slovenian Academy of Sciences and Arts.

Reduction in the volume of the Skuta Glacier is more apparent than reduction in its area (Table 1). When measurements started in 1946, the surface of the glacier was dozens of meters higher than it is today; this can be estimated using old measuring points that marked the edge of the glacier. Years ago these measurement points could be reached by hand; today they are 40 to $60 \mathrm{~m}$ higher on the walls of the cirque (Figure 7). In 2006 the thickness of the glacier was also measured in two longitudinal profiles of the glacier with the help of a steam drill. The average thickness of the glacier was $7 \mathrm{~m}$, and the greatest thickness was about $12 \mathrm{~m}$. Using the longitudinal profiles and transverse width of the glacier, its volume was estimated to be $80,000 \mathrm{~m}^{3}$ in 2006 (Pavšek, 2007).

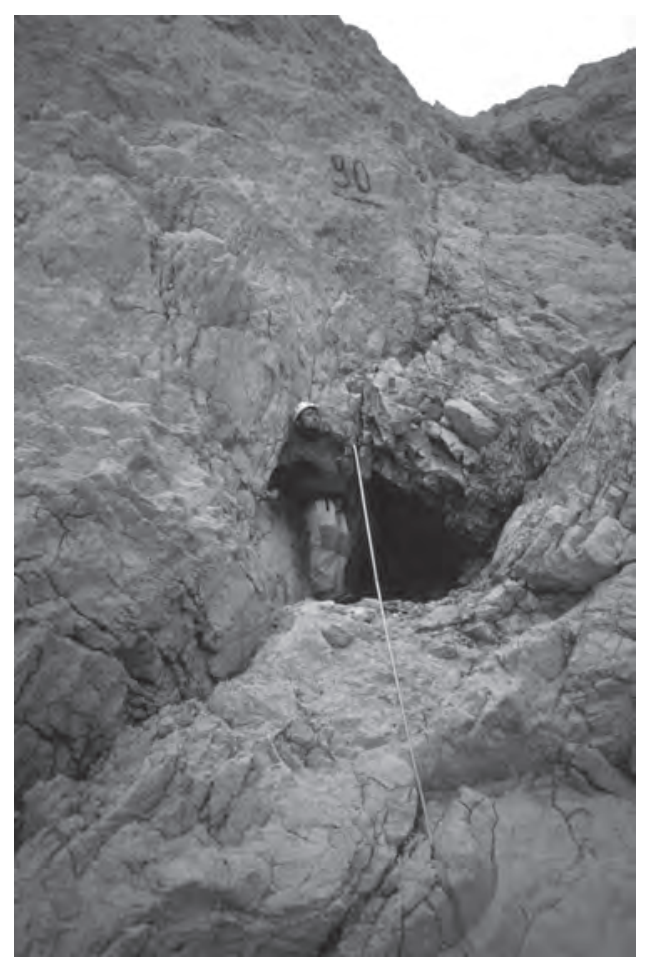

Figure 7: Miha Pavšek measures the vertical distance between an old measuring point from 1990 and the surface of the glacier in 1994. The surface of the glacier is below the lower frame of the photo (photo: Katja Kadiš). 

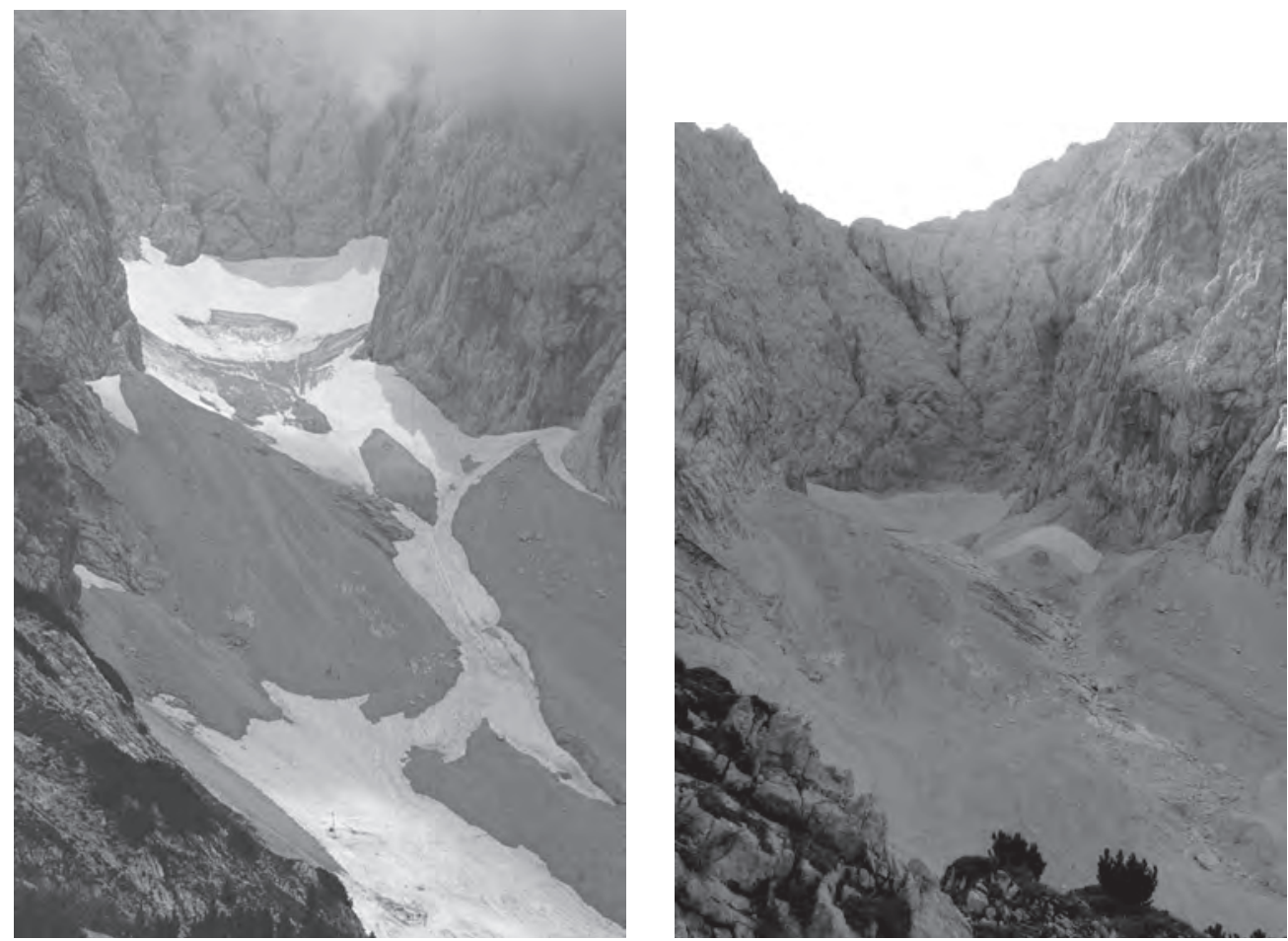

Figure 8: The Skuta Glacier photographed from a reference point by "a larch". Left: in 1982 (photo: Milan Šifrer), right: in 2008 (photo: Miha Pavšek).

Because the hiking routes around the Skuta Glacier are not as trafficked by hikers as those to Triglav, less historical photographic material is available from this area. The first (known) photos of the Skuta Glacier are the photos of the 1913 accident mentioned above (Figure 2; Meze 1955). Annual photos of the glacier using various non-metric cameras from two fixed reference points started being made in 1962 alongside regular measurements of the glacier at the end of the melting season (Šifrer and Košir, 1976). Approximate positions of the fixed points for the photos: the first is the lower edge of the Ledine Cirque and the second next to "a larch" at the fork in the trail to the Savinjsko sedlo and Rinke (Figure 8). This material is still waiting to be processed. 


\begin{tabular}{|c|c|c|c|c|}
\hline \multirow[b]{2}{*}{ Year } & \multicolumn{4}{|c|}{ Area (ha) } \\
\hline & $\begin{array}{l}\text { Triglav } \\
\text { Glacier }\end{array}$ & Measurement & $\begin{array}{l}\text { Skuta } \\
\text { Glacier }\end{array}$ & Measurement \\
\hline End of 19th c. & $>40$ & estimate & & \\
\hline 1900 & 30 & estimate & & \\
\hline 1937 & 27 & topographic map & & \\
\hline 1946 & 14.4 & tape measure & $2.5-3$ & tape measure \\
\hline 1948 & 16.0 & tape measure & & \\
\hline 1950 & 12.7 & tape measure & 2.8 & tape measure \\
\hline 1952 & 12.6 & geodetic measure & & \\
\hline 1959 & 10.9 & tape measure & & \\
\hline 1964 & 10.3 & tape measure & & \\
\hline 1973 & 11.9 & tape measure & & \\
\hline 1982 & 10.9 & Horizont camera & & \\
\hline 1989 & 6.8 & Horizont camera & 1.1 & tape measure \\
\hline 1992 & 4.0 & Horizont camera & & \\
\hline 1995 & 3.0 & geodetic measure & & \\
\hline 1997 & 2.9 & Horizont camera & 1.5 & geodetic measure \\
\hline 1999 & 1.1 & geodetic measure & & \\
\hline 2003 & 0.7 & geodetic measure & 0.7 & geodetic measure \\
\hline 2007 & 0.6 & geodetic measure & 1.1 & geodetic measure \\
\hline
\end{tabular}

Table 1: Decrease in the area of the Triglav and Skuta glaciers and measurement methods. The table shows the values for the years in which the glaciers were not completely covered by snow from the previous winter. After 2007 both glaciers were regularly covered with snow during the measurement time. When Horizont camera is listed in the table as a measuring technique the area of the glacier was estimated based on archival Horizont photos.

\section{AUSTRIAN GLACIERS}

Approximately one hundred Austrian glaciers are measured each year by members of the Austrian Alpine Society (Österreichischer Alpenverein) using simple measuring methods. They measure the retreat of the glacier with a tape measure every year from points marked in front of the glacier's terminus (Kaufmann and Ladstädter, 2004). Measurements started being made in 1891 (Finsterwalder et al., 1891). Today the measurements are made by various societies or individuals, and the data are collected by Andrea Fischer of Innsbruck, who also publishes an overall summary of the measurements every year in Bergauf, the journal of the Austrian Alpine Society (e.g., Fischer, 2012), and the data are also forwarded to the World Glacier Monitoring Service in Zürich. Tachymetric measurements of changes in glacial thickness/area, speed of 
movement of the ice, and changes in ice density (for studying the annual mass balance of the glacier) are carried out for only a few glaciers in Austria. They monitor the following glaciers for this purpose: the Pasterze, Goldbergkees, Kleinfleisskees, Stubacher Sonnblickkees, and Wurtenkees glaciers in the eastern part of the Austrian Alps, and the Jamtalferner, Hintereisferner, Kessselwandferner, and Vernagtferner glaciers in the west. The findings are published in annual reports (e.g., Zemp et al., 2011). Data on the annual mass balance of these glaciers are contributed to the Global Terrestrial Network for Glaciers (GTN-G; http://www.gtn-g.org/).

Because other measurements mostly do not provide information about changes in the area and decrease in thickness of the glaciers, two glacier inventories have been carried out in Austria; the first in 1969 (Patzelt, 1980) and the second in 1998 (Lambrecht and Kuhn, 2007). Inventories were made with the help of photogrammetric stereo-acquisition and semi-automatic production of digital terrain models. As part of the first inventory, the area of Austrian glaciers was determined for the time of their greatest extent in the period between 1850 and 1920 (Gross, 1987). Some of the findings are presented in Table 2.

\begin{tabular}{|l|l|l|l|}
\hline Year & $\begin{array}{l}\text { Number of } \\
\text { glaciers }\end{array}$ & $\begin{array}{l}\text { Total area of } \\
\text { glaciers }\left(\mathrm{km}^{2}\right)\end{array}$ & $\begin{array}{l}\text { Total volume } \\
\text { of glaciers } \\
\left(\mathrm{km}^{3}\right)\end{array}$ \\
\hline 1850 & $/$ & 946 & $/$ \\
\hline 1920 & $/$ & 759 & $/$ \\
\hline 1969 & 925 & 567 & 22.8 \\
\hline 1998 & $\sim 900$ & 471 & 17.7 \\
\hline
\end{tabular}

Table 2: Number, total area, and estimated volume of Austrian glaciers (Gross, 1987; Lambrecht and Kuhn, 2007).

In addition to general measurements used to monitor overall ice cover in Austria, individual institutions are also carrying out many studies (including geodetic ones) on individual glaciers for detailed examination of changes in the glaciers. Below we present the measurements for two glaciers that are carried out by the Institute of Geography and Regional Studies at the University of Graz and the Institute of Remote Sensing and Photogrammetry at the Graz University of Technology.

\subsection{Measurement of the Gössnitzkees and Hornkees glaciers}

The neighboring Gössnitzkees and Hornkees cirque glaciers are part of the Schober mountain group (Schobergruppe) in the High Tauern range (Hohe Tauern). Similar to the Slovenian glaciers, they are located at relatively low elevations and have a small accumulation area. In contrast to the Triglav and Skuta glaciers, however, they are much larger because in 2006 they measured 58.9 and 30.6 ha. Another reason we used them as a comparison for the Slovenian glaciers is because their size has been calculated in a similar way from various sources all the way back to 1873 , and the measurement methods are well documented. Because the glaciers are located 
in an area that is not too heavily trafficked by hikers, the probability of old photos existing is also small here. One of the oldest photos is presented in Figure 9, and Figure 10 shows a more recent comparable combined view of the glaciers.

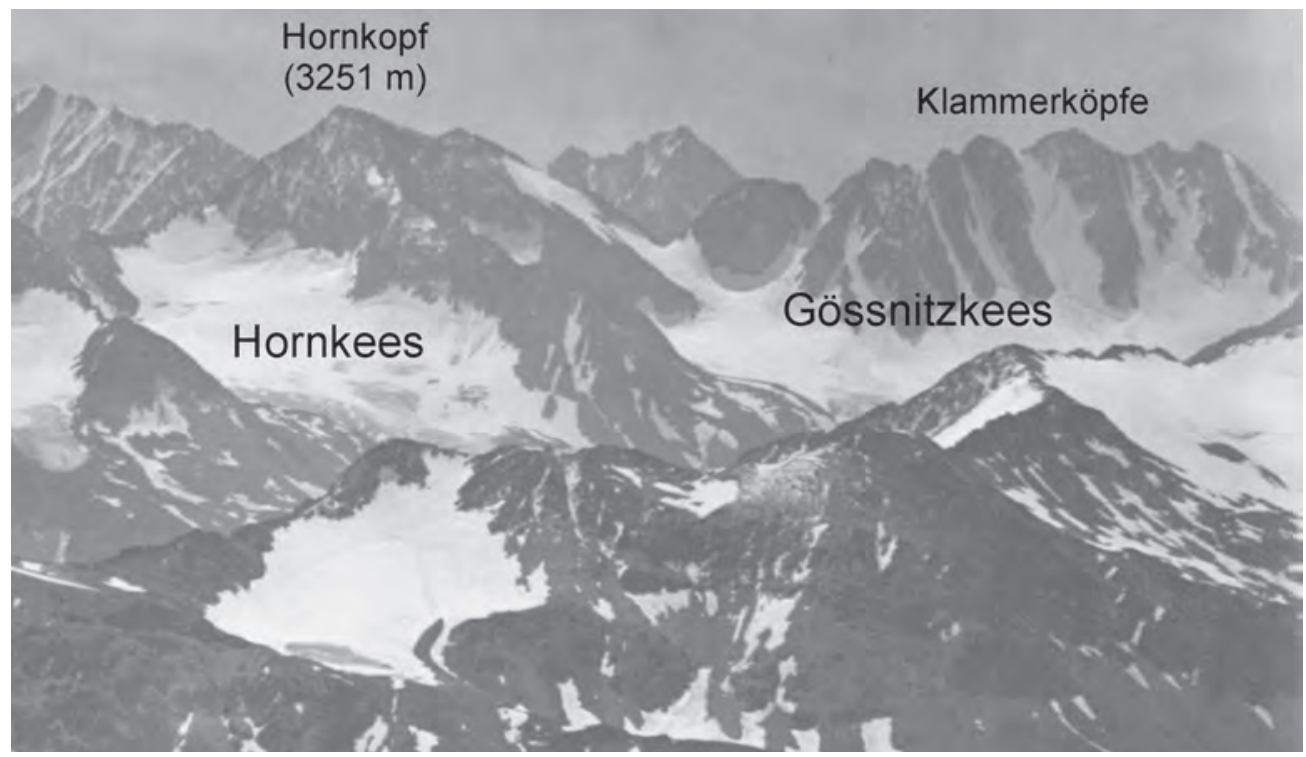

Figure 9: Terrestrial photo of the Gössnitzkees and Hornkees glaciers from 1863, taken from a camera station near Mount Grossglockner facing the southeast (photo: Gustav Jägermayer @)Albertina, Vienna, http://www.albertina.at/).

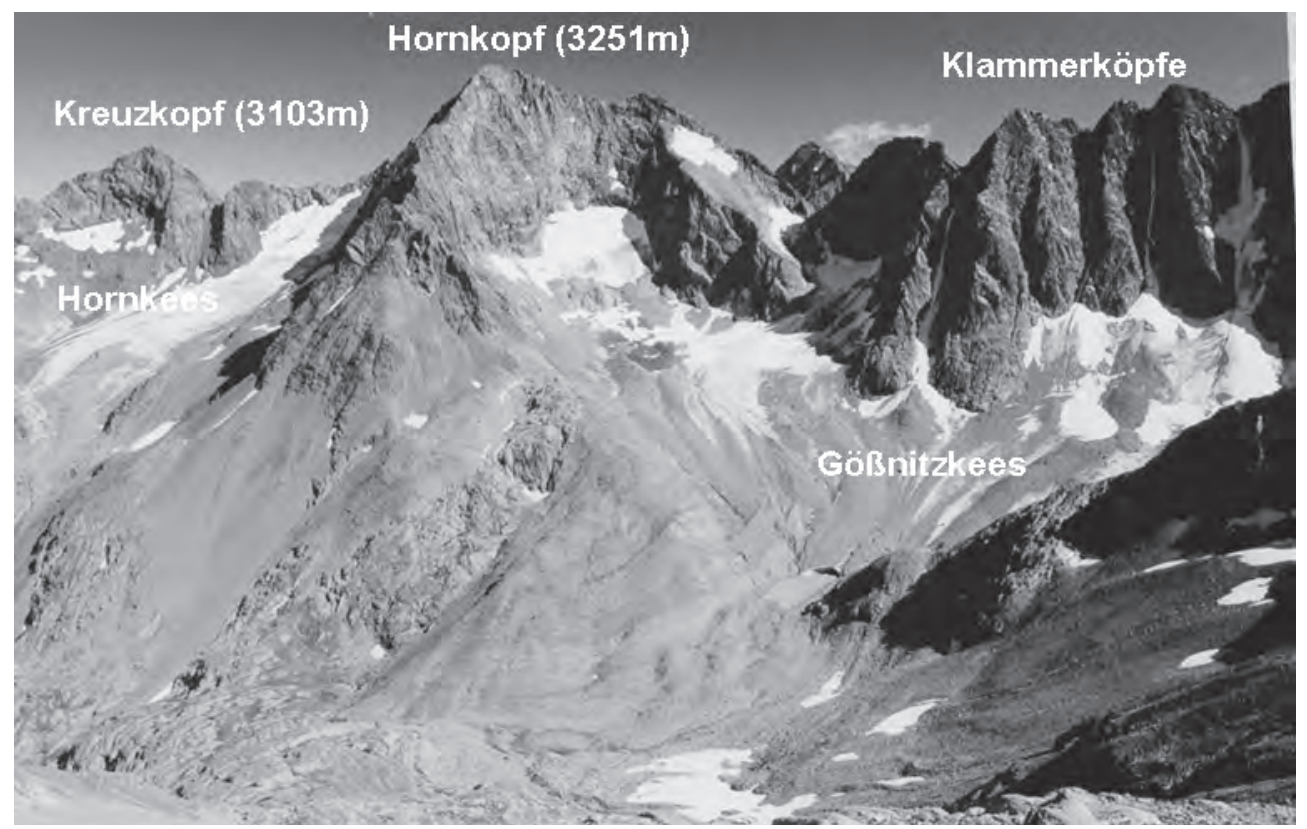

Figure 10: Terrestrial photo of the Gössnitzkees and Hornkees glaciers taken in the summer of 1997 from Mount Roter Knopf (photo: Gerhard Karl Lieb). 
There are over thirty peaks exceeding 3,000 $\mathrm{m}$ in the Schober mountain group in the High Tauern range; the highest is Mount Petzek (3,283 m). In 1969 the Schober mountain group had twenty-nine small glaciers with an average area of $18 \mathrm{ha}^{3}$. The Gössnitzkees and Hornkees glaciers are the largest glaciers in this mountain group. The Gössnitzkees Glacier is distinguished by nearly two-thirds of its surface being covered by debris. The neighboring Hornkees Glacier is less debris-covered, mostly only on its margins. However, its elevation distribution is more favorable for the long-term existence of the glacier because the majority of it lies slightly higher than the neighboring Gössnitzkees Glacier. The lowest part of the Gössnitzkees Glacier was at an elevation of 2,465 $\mathrm{m}$ in 1850 , and in 1997 was at 2,515 $\mathrm{m}$; the highest part of the glacier is at 3,000 $\mathrm{m}$. The lowest part of the Hornkees Glacier was at 2,406 $\mathrm{m}$ in 1850 and at 2,600 m in 1996. The Gössnitzkees Glacier also has a glacial lake that is fed by the glacier in the summer months. In contrast to the small glacial lakes of the Triglav Glacier from the 1960s, in 2006 the Gössnitzkees glacial lake measured 0.7 ha (Kaufmann and Lieb, 2002; Kaufmann and Ladstädter, 2008a.)

The size of the Gössnitzkees and Hornkees glaciers in 1873 and 1929 was vectorized from old topographic maps. The size from 1873 is dubious because the glaciers on that map were poorly represented. The first topographic map on which the glacial contour lines were well represented was from 1929 (Kaufmann and Ladstädter, 2008a).

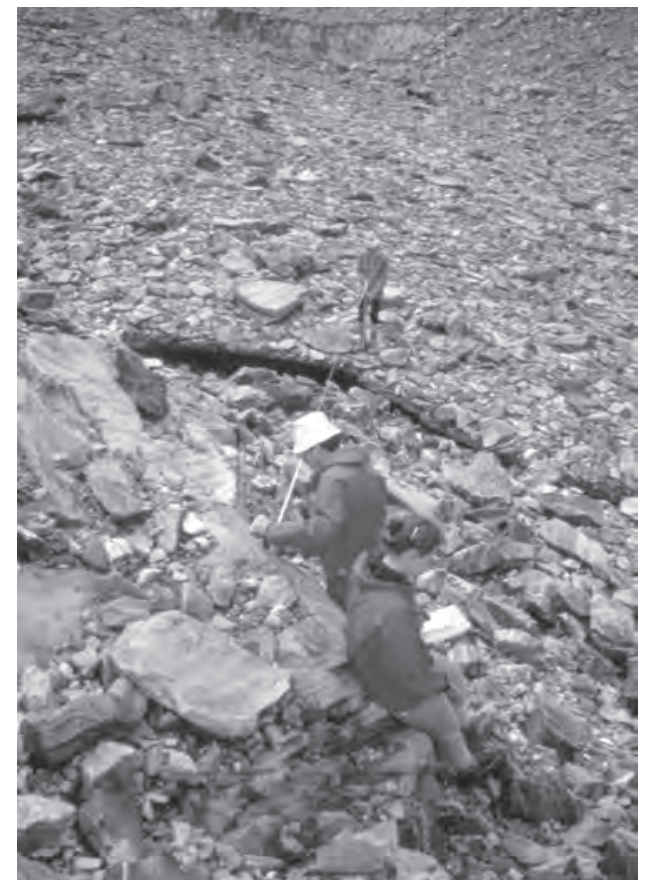

Figure 11: The second measurement of Gössnitzkees glacial retreat with a tape measure in 1983, made from the reference point stabilized in 1982. Viktor Kaufmann is standing on the edge of the glacier, which is covered by large amounts of debris, Gerhard Karl Lieb is reading the distance on the tape measure, and Bettina Hofer is writing in the measurement log (photo: Elmar Joura).

${ }^{3}$ At that time, the Triglav Glacier also measured approximately $15 \mathrm{ha}$. 
The first measurements of the Gössnitzkees Glacier were made by Lieb and Kaufmann in 1982. First they used a tape measure to measure the retreat of the glacier's terminus from two fixed measuring points that were marked with durable paint on firm rock in 1982 (Figure 11). The coordinates of the points were calculated in a local coordinate system with trilateration. A year later they also measured the neighboring Hornkees Glacier. Since then both glaciers have been measured every year by associates from the Institute of Geography and Regional Studies at the University of Graz and the Institute of Remote Sensing and Photogrammetry at the Graz University of Technology. In 1996 the former Institute of Geodesy at the University of Graz chose the Gössnitzkees Glacier as a test area for their alpine studies (Kaufmann, 2012).
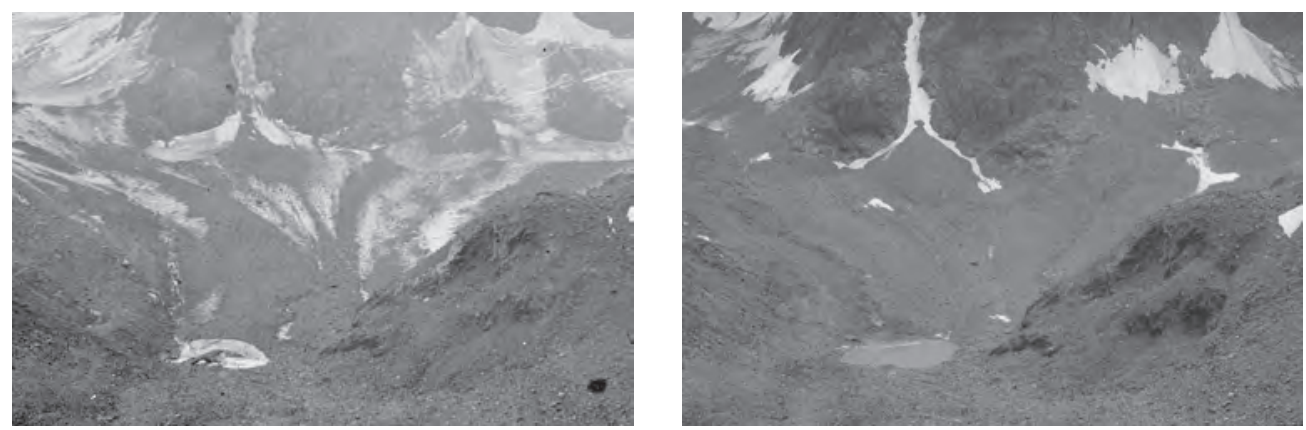

Figure 12: Terrestrial view of the central part of the Gössnitzkees Glacier. Left: a photo from 7 September 1988 taken with a Zeiss TAL photo-theodolite (photo: Robert Kostka and Viktor Kaufmann). Right: a photo from 20 August 2010 taken with a Nikon D300 digital camera. The photo at right also shows the glacial lake. The photos were taken from the same reference camera station (photo: Viktor Kaufmann).

Before 1954 there were no metric terrestrial or aerial photos of both glaciers made, and so the size of the glacier for 1850 was defined based on field studies of the glacier's terminal and lateral moraines. The greatest extent of the glaciers can also be seen based on glacial moraines visible in recent aerial photos. The state of the glaciers in 1954, 1969, 1974, 1983, 1992, 1997, 2002, and 2006 was measured based on aerial photogrammetry (the photos are archived at the Austrian Federal Office of Metrology and Surveying - Bundesamt für Eich-und Vermessungswesen). Additional aerial photogrammetry was carried out in 1997 and 1998. Most of the photos were taken in September, which usually represents the end of the glacial melting period. Exceptions include 1969 (taken in October), 1983 (taken in July), and 1998 (taken at the end of August). Photogrammetric acquisition of all of the aerial photos from various sources was made using the joint coordinate system of the Austrian Gauss-Krüger cartographic projection at a scale of 1:5,000. Contour lines, break lines, ridges, watersheds, elevation points, edges of snowfields and glaciers, and other topographic content was analyzed. In places it was difficult to delimit the glaciers because they ware partially covered with debris. Stereo acquisition was also impeded in places where the glacier was brightly lit by sun or was in deep shade (Kaufmann and Ladstädter, 2002; Kaufmann and Ladstädter, 2008a).

Terrestrial photos have also been taken on part of the Gössnitzkees Glacier since 1988. The glacier is measured at its longest and thickest profile in its central part, where the thinning of the glacier is measured using photogrammetry. Terrestrial photogrammetry was carried out in 
1988, 1997, 2003, 2004, 2005, 2006 and 2007. In the first year standard photos were taken from two stabilized reference points, and in the following years these were joined by two additional stabilized reference points. The reference points were stabilized with screws. The reference points were selected such that the test section of the glacier could be seen in only one stereo pair (Figure 12). In those years they used various metric and non-metric (retroactively calibrated) cameras. In 1988 they used a Zeiss TAL photo-theodolite with a glass plate measuring $6 \mathrm{~cm} \times 6 \mathrm{~cm}$, in 1997 and 2003 a medium-format Rollemetric 6006 metric camera, in 2004, 2005, and 2006 a small-formal non-metric Nikon D100 digital camera, in 2006 also a high-quality non-metric Hasselblad H2D-39 digital camera, and in 2007 a non-metric Nikon D80 digital camera. The non-metric cameras were set to infinity during use and calibration. They were calibrated with the help of calibration targets included in the Photomodeler program. The first seven natural features that were included as control points were already measured in a local coordinate system using a photo-theodolite in 1988. It was later determined that these points were not sufficiently precisely defined for the desired precision of photogrammetric acquisition, and so in 2003 ten new natural features were tachymetrically measured and these were taken as control points for absolute orientation in the national coordinate system. Based on the absolutely oriented stereo pair from 2003, they measured an additional fifty-five photogrammetric control points. Thus there are altogether sixty-five control points available for the absolute orientation of stereo pairs (Kaufmann in Ladstädter, 2004; Kaufmann and Ladstädter, 2008b).

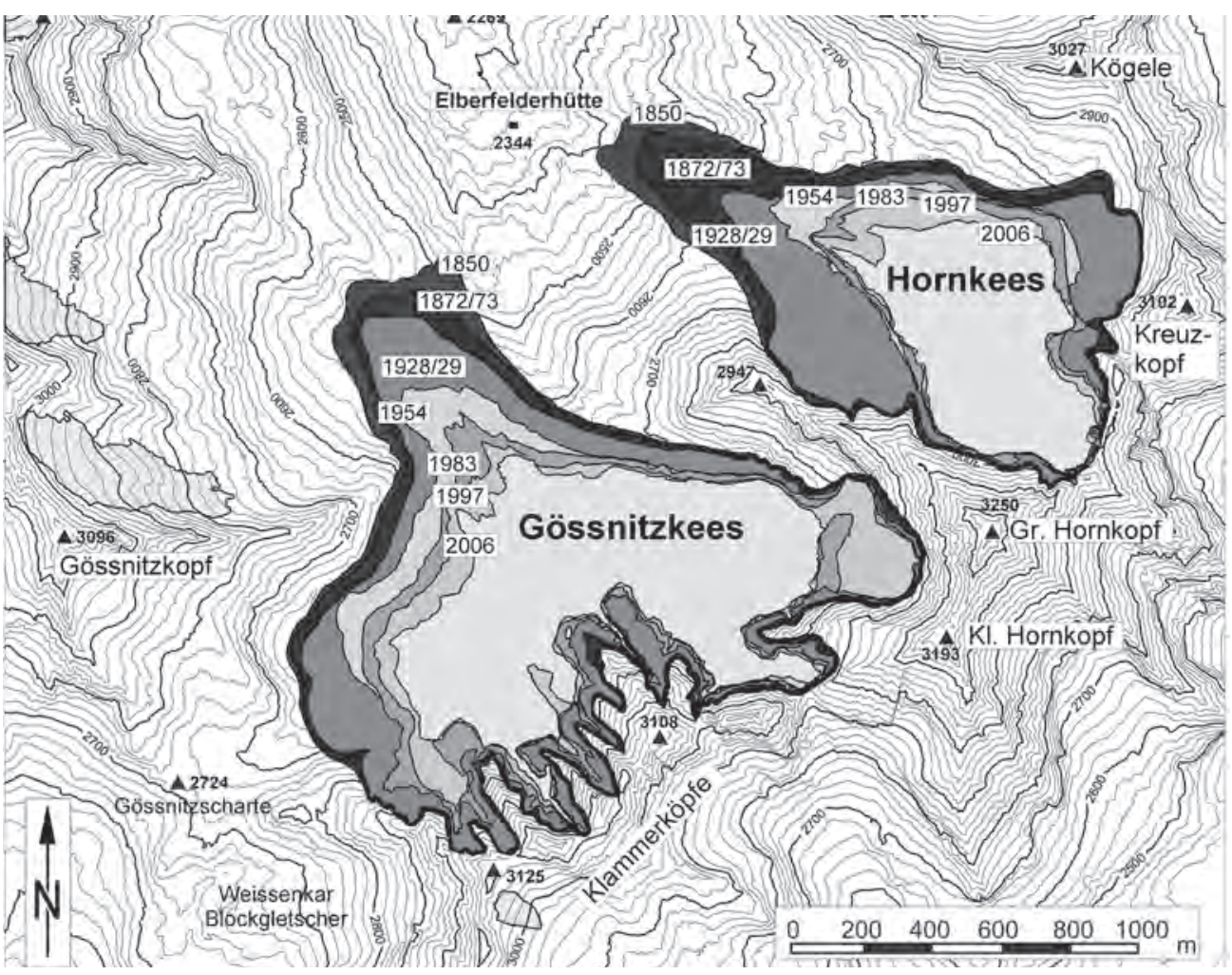

Figure 13: Reduction in area of the Gössnitzkees and Hornkees glaciers (Table 3). 
The lower part of the Gössnitzkees Glacier has also been tachymetrically measured every year since 1996. They measure the retreat of the glacier's terminus, the rim of the glacial lake, the movement of the glacier from ten stabilized points, and two profiles of the glacier up to an elevation of $2,570 \mathrm{~m}$. Above this elevation the glacier is too steep for setting up geodetic reflectors for measuring distances every year. Based on the measurements, the speed of the glacial movement has been determined to be between 0.2 and 0.5 m per year (Kienast and Kaufmann, 2004; Kaufmann and Ladstädter, 2004).

The area of the glaciers between 1873 and 2006 are presented in Figure 13, and Table 3 also presents the measurement methods.

\begin{tabular}{|c|c|c|c|}
\hline \multirow[b]{2}{*}{ Year } & \multicolumn{3}{|l|}{ Area (ha) } \\
\hline & $\begin{array}{l}\text { Gößnitzkees } \\
\text { Glacier }\end{array}$ & $\begin{array}{l}\text { Hornkees } \\
\text { Glacier }\end{array}$ & Measurement \\
\hline 1873 & 146.1 & 84.4 & topographic map \\
\hline 1929 & 132.3 & 70.5 & topographic map \\
\hline 1954 & 97.3 & 43.9 & aerial photo stereo-acquisition \\
\hline 1969 & 93.3 & 42.2 & aerial photo stereo-acquisition \\
\hline 1974 & 89.9 & 41.7 & aerial photo stereo-acquisition \\
\hline 1983 & 90.1 & 41.3 & aerial photo stereo-acquisition \\
\hline 1992 & 78.3 & & aerial photo stereo-acquisition \\
\hline 1997 & 75.7 & 36.1 & aerial photo stereo-acquisition \\
\hline 2002 & 63.3 & 33.0 & aerial photo stereo-acquisition \\
\hline 2006 & 58.8 & 30.6 & aerial photo stereo-acquisition \\
\hline
\end{tabular}

Table 3: Reduction in area of the Gössnitzkees and Hornkees glaciers and measurement methods.

\section{CONCLUSION}

Comparable measurement techniques are being used on the glaciers presented; however, due to the size differences between the Austrian and Slovenian glaciers a direct comparison is not the most appropriate, despite the fact that certain trends are visible (Table 4). As shown in Tables 1 and 2, the measures for the Gössnitzkees and Hornkees glaciers at their smallest size in 2006 were 58.9 ha and 30.6 ha, respectively. The smallest measured area for the Triglav Glacier was 0.6 ha in 2007, and for the Skuta Glacier 0.7 ha in 2003.

Table 3 compares the reduction in size of the Triglav Glacier versus the Gössnitzkees and Hornkees glaciers. Their accelerated reduction is apparent from the 1930s to the 1950s, when they lost an average of a hectare per year. From the middle of the century until the 1980s, the glacier retreat stagnated in all three glaciers, which mostly lost about 0.1 ha per year. After 1983 the glacier loss of area accelerated again. The last two periods are not directly comparable because of the small area of the Triglav Glacier (about 1 ha). 


\begin{tabular}{|l||l|l|l|l|}
\cline { 2 - 5 } \multicolumn{1}{c|}{} & \multicolumn{4}{l}{ Annual glacial fluctuation (ha/year) } \\
\hline Period & Gössnitzkees & Hornkees Glacier & Period & $\begin{array}{l}\text { Triglav } \\
\text { Glacier }\end{array}$ \\
\hline $1873 / 1929$ & -0.25 & -0.25 & & \\
\hline $1929 / 1954$ & -1.40 & -1.06 & $1937 / 1954$ & -0.80 \\
\hline $1954 / 1969$ & -0.27 & -0.11 & $1954 / 1967$ & -0.10 \\
\hline $1969 / 1974$ & -0.67 & -0.10 & $1967 / 1973$ & 0.00 \\
\hline $1974 / 1983$ & +0.03 & -0.05 & $1973 / 1983$ & -0.18 \\
\hline $1983 / 1992$ & -1.32 & $-0.37(1983 / 1997)$ & $1983 / 1992$ & -0.64 \\
\cline { 2 - 3 } & -0.52 & & $1992 / 1997$ & -0.28 \\
\hline $1992 / 1997$ & -2.46 & -0.62 & $1997 / 2003$ & -0.37 \\
\hline $2002 / 2006$ & -1.12 & -0.60 & $2003 / 2007$ & -0.03 \\
\hline
\end{tabular}

Table 4: Annual fluctuation in the area of the Gössnitzkees, Hornkees, and Triglav glaciers. The annual value is calculated by dividing the difference in area by the number of years in the given period.

The alpine glaciers share the fact that in recent centuries they reached their greatest size in the mid-nineteenth century (Zängl and Hamberger, 2004), during one of the peaks of the Little Ice Age (Fagan, 2000). In 1870 Alpine glaciers covered around 4,400 $\mathrm{km}^{2}$ (just over $2 \%$ of the Alps) and their volume was about $200 \mathrm{~km}^{3}$. By the 1970 s their total volume had decreased to $140 \mathrm{~km}^{3}$, and by the beginning of the twenty-first century they had lost another one-third of their volume (around $90 \mathrm{~km}^{3}$ ). Thus in just over a century and a half the volume of alpine glaciers decreased by over half, and the area by approximately one-third (Haeberli et al., 2007; Haeberli and Beniston, 1998; Funk-Salamí, 2004; Zängl and Hamberger, 2004; Barry, 2006). These changes are connected with various climate changes (Kerschner, 2002). For the Triglav Glacier area it has been determined that today, in comparison with past periods, the spring snow cover is thinner, the summer temperatures are higher, and there is more insolation during the melting season (Dolinar, 2010). Among climate changes, attention is most often drawn to higher average annual temperatures. At the Triglav Glacier the average summer temperature in the mid-nineteenth century was below $5^{\circ} \mathrm{C}$, and in 2010 it was around $6.5^{\circ} \mathrm{C}$. According to predictions, the trend of rising temperatures will continue, and by the end of the twenty-first century the average annual temperature in the Alps is expected to have risen by 1.4 to $5.6^{\circ} \mathrm{C}$ (Maisch, 2004). Based on these scenarios, alpine glaciers face a similar fate as before the Little Ice Age. In the short term it is small alpine glaciers that are most threatened, especially those at relatively low elevations (e.g., the two Slovenian glaciers), as well as small glaciers at similar elevations but at lower latitudes; for example, in Albania (Hughes, 2010), Montenegro (Djurović, 2012), or Bulgaria (Grunewald and Scheithauer, 2010), to mention only the Balkans.

In the case of the two Slovenian glaciers and the two Austrian glaciers, it can be seen that, in 
addition to geodetic and photogrammetric methods of measurement for studying glaciers, in many cases approximate measurement with a tape measure is still being used. The set of various measurements in various time periods can indicate a detailed long-term trend of glacial retreat. Today, however, aerial laser scanning is also increasingly being used to monitor glaciers, which offers a more detailed impression of the surface of the glacier itself (e.g., Abermann et al., 2009). Such measurements will also be made on the Slovenian glaciers in 2012.

\section{ACKNOWLEDGEMENT}

This work was partly supported by Slovenian Research Agency (ARRS) through projects L6-7136 (C) and Z2-4182 (B) and by the Austrian Science Fund (FWF) through project FWF P18304-N10.

\section{References:}

Abermann, J., Lambrecht, A., Fischer, A., Kuhn, M. (2009). Quantifying changes and trend in glacier area and volume in the Austrian Otztal Alps (1969-1997-2006), The Cryosphere, 3, 205-215.

Avian, M., Bauer, A. (2006). First results on monitoring glacier dynamics with the aid of the terrestrial laser scanning on Pasterze glacier (Hohe Tauern, Austria). Glazier Schriften der Geographie und Raumforschung, 41, 27-36.

Barry, R. G. (2006). The status of research on glaciers and global glacier recession: a review. Progress in Physical Geography, 30(3), 285-306.

Bayr, K. J., Hall, D. K., Kovalick, W. M. (1994). Observations on glaciers in the eastern Austrian Alps using satellite data. International Journal of Remote Sensing, 15, 1733-1742.

Bolch, T., Kamp, U. (2006). Glacier mapping in high mountains using DEMs, Landsat and ASTER data. Glazier Schriften der Geographie und Raumforschung, 41, 37-48.

Djurović, P. (2012). The Debeli Namet glacier (Durmitor, Montenegro) - From the second half of the 20th century to the present. Acta geographica Slovenica, 52 (in press).

Dolinar, M. (ur.) (2010). Spremenljivost podnebja v Sloveniji. Ljubljana: Agencija Republike Slovenije za okolje. http:// meteo.arso.gov.si/uploads/probase/www/climate/text/sl/publications/spremenljivost\%20podnebja.pdf. (2. 4. 2012).

Fagan, B. (2000). The Little Ice Age: How Climate Made History, 1300-1850. New York: Basic Books.

Finsterwalder, S., Hann, J., Partsch, J., Penck, A., Richter, E. (1891). Aufruf. Mitteilungen des Deutschen und Österreichischen Alpenvereins, 17(8), 106-107.

Fischer, A. (2012). Gletscherbericht 2010/2011. Bergauf 67(2), 30-36.

Funk-Salamí, F. (2004). Naturwunder aus Eis. In Gletscher im Treibhaus. Steinfurt: Tecklenborg Verlag, 194-199.

Gabrovec, M. (2002). Triglavski ledenik = The Triglav glacier. In Visokogorska jezera v vzhodnem delu Julijskih Alp = High-Mountain Lakes in the Eastern Part of the Julian Alps. Ljubljana: Založba ZRC, 37-48.

Gabrovec, M. (2008). II ghiacciaio del Triglav (Slovenia) = The Triglav glacier. Ghiacciai montani e cambiamenti climatici nell' ultimo secolo. Terra glacialis - Edizione speciale, 75-87.

Gross G. (1987). Der Flächenverlust der Gletscher in Österreich 1850-1920-1969. Zeitschrift für Gletscherkunde und Glazialgeologie, 23(2), 131-141.

Grunewald, K., Scheithauer, J. (2010). Europe's southernmost glaciers: response and adaptation to climate change. Journal of Glaciology, 56(195), 129-141.

Haeberli, W., Beniston, M. (1998). Climate change and its impacts on glaciers and permafrost in the Alps. Ambio, 27(4), 258-265.

Haeberli, W., Hoelzle, M., Paul, F., Zemp, M. (2007). Integrated monitoring of mountain glaciers as key indicators of global climate change: the European Alps. Annals of Glaciology, 46(1), 150-160.

Hagg, W., Mayer, C., Steglich, C. (2008). Glacier changes in the Bavarian Alps from 1989/90 to 2006/2007. Zeitschrift für Gletscherkunde und Glazialgeologie, 42(1), 37-46. 
Hughes, P. D. (2010). Little Ice Age glaciers in the Balkans: low altitude glaciation enabled by cooler temperatures and local topoclimatic controls. Earth Surface Processes and Landforms, 35, 229-241.

Kaufmann, V., Lieb, G. K. (2002). Investigation on the retreat of two small cirque glaciers (Goessnitzkees and Hornkees) in the Austrian Alps, Europe. Hight-Mountain Remote Sensing Cartography 1998: 5th International Symposium on the Use of Remote Sensing Data in Mountain Cartography, Karlstad University Studies, 27, 75-82.

Kaufmann, V., Ladstädter, R. (2004). Documentation of the retreat of small debries-covered cirque glacier (Gössnitzkees, Austrian Alps) by means of terrestrial photorammetry. 4th ICA Mountain Cartography Workshop, 65-76.

Kaufmann, V., Ladstädter, R. (2008a). Documentation of the retreat of Gössnitzkees and Hornkees glaciers (Hohe Tauern Range, Austria) for the time period 1997-2006 by means of aerial photogrammetry. 6th ICA Mountain Mapping and Visualisation, 131-139.

Kaufmann, V., Ladstädter, R. (2008b). Application of terrestrial photogrammetry for glacier monitoring in Alpine environments. The International Archives of the Photogrammetry, Remote Sensing and Spatial Information Sciences, 37, part B8, 813-818.

Kaufmann, V. (2012). Goessnitzkees (Carinthia, Austria), www.geoimaging.tugraz.at/viktor.kaufmann/Goessnitzkees. html (2. 4. 2012).

Kerschner, H. (2002). Gletscher-Klima-Beziehungen als klimageschichtliche Werkzeuge. Grazer Schriften der Geographie und Raumordnung, 38, 143-158.

Kienast, G., Kaufman, V. (2004). Geodetic measurements on glaciers and rock glaciers in the Hohe Tauern National Park (Austria). 4th ICA Mountain Cartography Workshop. www.geoimaging.tugraz.at/viktor.kaufmann/HMC2004_ Kienast.pdf. (2. 4. 2012).

Knoll, C., Kerschner, H. (2009). A glacier inventory for South Tyrol, Italy, based on airborne laser-scanner data. Annals of Glaciology, 50(53), 46-52.

Kunaver, J. (1913). Nesreča na Skuti. Planinski vestnik, 19(8), 170-175.

Kunaver, P. (1949). Izpremembe okoli Triglava. Planinski vestnik, 49, 65-75.

Kuhn, M. (1979). Climate and Glaciers, Sea Level, Ice, and Climatic Change (Proceedings of the Canberra Ayplosium, December 1979). IAHS Publication, 131, 3-20.

Lambrecht, A., Kuhn, M. (2007). Glacier changes in the Austrian Alps during the last three decades, derived from the new Austrian glacier inventory. Annals of Glaciology, 46, 177-184.

Lieb, G. K. (2004). Die Pasterze als Beispiel eines schwindenden Gletschers. In Gletscher im Treibhaus. Steinfurt: Tecklenborg Verlag, 216-219.

Maisch, M. (2004). Gletscher im Brennpunkt des Klimawandels. In Gletscher im Treibhaus. Steinfurt: Tecklenborg Verlag, 204-214.

Pavšek, M. (2007). Ledenik pod Skuto kot pokazatelj podnebnih sprememb v slovenskem delu Alp. Dela, 28, 207-219.

Patzelt G. (1980). The Austrian glacier inventory: status and first results. Proceedings of the Riederalp Workshop. IAHS Publication, 126, 181-183.

Meze, D. (1955). Ledenik na Triglavu in Skuti. Geografski zbornik, 3, 10-114.

Natek, M., Perko, D. (1999). 50 let Geografskega inštituta Antona Melika ZRC SAZU. Geografija Slovenije, 1. Ljubljana: Založba ZRC.

Šifrer, M. (1963). Nova geomorfološka dognanja na Triglavu. Triglavski ledenik v letih 1954-1962. Geografski zbornik, 8, 157-210.

Šifrer, M., Košir, D. (1976). Nova dognanja na Triglavskem ledeniku in ledeniku pod Skuto. Geografski zbornik, 15, 213-269.

Triglav, M., Kosmatin Fras, M., Gvozdanovič, T. (2000). Monitoring of glacier surfaces with photogrammetry, a case study of the Triglav Glacier. Geografski zbornik, 40, 7-30.

Triglav Čekada, M., Gabrovec, M. (2008). Zgodovina geodetskih meritev na Triglavskem ledeniku. Geodetski vestnik, 52(3), 508-519.

Triglav Čekada, M., Radovan, D., Gabrovec, M., Kosmatin Fras, M. (2011). Acquisition of the 3D boundary of the 
Triglav glacier from archived non-metric panoramic images. The Photogrammetrical Record, 26(133), 111-129.

Triglav Čekada, M. (2012). Geodetske in fotogrametrične meritve Triglavskega ledenika. Raziskave s področja geodezije in geofizike 2011: zbornik predavanj, 7-17.

Triglav Čekada, M., Gabrovec, M. (2012). Documentation of Triglav glacier using non-metric panoramic images, Annals of Glaciology, IGS: Seasonal snow and ice conference (in press).

Verbič, T., Gabrovec, M. (2002). Georadarske meritve na Triglavskem ledeniku. Geografski vestnik, 74(1), $25-42$.

Zängl, W., Hamberger, S. (2004). Gletscher im Treibhaus. Steinfurt: Tecklenborg Verlag.

Zemp, M., Nussbaumer, S. U., Gaertner-Roer, I., Hoelzle, M., Paul, F., Haeberli, W. (ur.) (2011). Glacier mass balance bulletin. Bulletin, 11 (2008-2009). Zürich: World Glacier Monitoring Service. www.wgms.ch/mbb/mbb11/ wgms_2011_gmbb11.pdf(2. 4. 2012).

Received for publication: 22 June 2012

Accepted: 2 September 2012

Mihaela Triglav Čekada, Ph. D. in Geodesy, B. Sc. in Geodesy

Geodetic Institute of Slovenia

Jamova 2, SI-1000 Ljubljana

e-mail:mihaela.triglav@gis.si

Matija Zorn, Ph. D. in Geography, B. Sc. in Geography and History, Assist. Prof.

Anton Melik Geographical Institute, Scientific Research Centre of the Slovenian Academy of Sciences and Arst Gosposka ulica 13, SI-1000 Ljubljana

e-mail:matija.zorn@zrc-sazu.si

Viktor Kaufmann, Ph. D., Assoc. Prof.

Institute of Remote Sensing and Photogrammetry, Graz University of Technology

Steyrergasse 30, A-8010 Graz, Austria

e-mail:viktor.kaufmann@tugraz.at

Gerhard Karl Lieb, Ph. D., Assoc. Prof.

Institute of Geography and Regional Sciences, Karl-Franzens University of Graz

Heinrichstraße 36, A-8010 Graz, Austria 